\title{
Population dynamics and management of yellow stem borer (Scirpophaga incertulas Walker) with insect sex-pheromone trap
}

AMIT KUMAR, A.K. MISRA, PAIDI SATYANARAYANA* AND JITENDRA KUMAR

Department of Entomology, Rajendra Agricultural University, Pusa, SAMASTIPUR (BIHAR) INDIA

\section{ARITCLE INFO}

Received : 13.03 .2015

Revised : 03.03 .2015

Accepted : 17.03 .2015

\section{KEY WORDS :}

Yellow stem borer, Sex-pheromone trap, Rice, IPM, Relative humidity, Rainfall
*Corresponding author: Email: psnento@gmail.com

\begin{abstract}
Field experiment was conducted at the Research Farm, Rajendra Agricultural University, Pusa. Pest activity started from $30^{\text {th }}$ standard week and continued upto $41^{\text {st }}$ standard week, meanwhile it reached peak twice in $34^{\text {th }}$ and $37^{\text {th }}$ standard week. Thereafter, its population declined and finally no population was recorded. Correlation and multiple regression between weather parameters and the population of male yellow stem borer moth revealed that maximum temperature $\left({ }^{\circ} \mathrm{C}\right)$, minimum temperature $\left({ }^{\circ} \mathrm{C}\right)$, relative humidity $(\%)$ at $7 \mathrm{hr}$, relative humidity $(\%)$ at $14 \mathrm{hrs}$, rainfall $(\mathrm{mm})$ and evaporation $(\mathrm{mm})$ were positively correlated to the tune of $0.273,0.453,0.075,0.478,0.339$ and 0.122 , respectively with the population of male moth of yellow stem borer, whereas, sunshine (hr) was negatively correlated (-0.453) to that. Weather parameters were found to contribute about 34.60 per cent male moth population fluctuation of Scirpophaga incertulas when acted together. Further, the IPM package reduced the infestation $(4.20,8.82,9.31 \% \mathrm{DH}$ and $9.41 \% \mathrm{WEH})$ caused by rice yellow stem borer in respect to untreated control $(4.88,23.75,27.68 \% \mathrm{DH}$ and $22.72 \% \mathrm{WEH})$ at 15, 30, 50 and 90DAT. Moreover, IPM package gave higher yield (50.25 q/ha) as compared to the control ( $41.80 \mathrm{q} / \mathrm{ha})$. It was also observed that net profit over the control was Rs. 11,825 with cost benefit ratio 1:2.27 with IPM package in both the years of study.
\end{abstract}

How to view point the article : Kumar, Amit, Misra, A.K., Satyanarayana, Paidi and Kumar, Jitendra (2015). Population dynamics and management of yellow stem borer (Scirpophaga incertulas Walker) with insect sex-pheromone trap. Internat. J. Plant Protec., 8(1) : 157-161. 